\title{
Use of a Chlorophyll Meter for Nondestructive and Rapid Estimation of Leaf Tissue Nitrogen in Macadamia
}

\author{
Russell Galanti ${ }^{1}$, Alyssa Cho, Amjad Ahmad, and Javier Mollinedo
}

ADDITIONAL INDEX wORDs. SPAD, nutrient analysis, fertilizer management, seasonality, iron

SUMmARY. Nitrogen (N) management in macadamia (Macadamia integrifolia) orchards is an important concern for growers. Leaf tissue analysis is the accepted method for determining $\mathbf{N}$ status in macadamia; however, this process is expensive and time-consuming. The chlorophyll meter has been used in other crops to estimate $\mathrm{N}$ status in plants through estimation of the amount of chlorophyll in leaf tissue. The use of the chlorophyll meter in two macadamia cultivars (Kakea and Kau) at two locations in Hawai'i (Kapa'au and Pahala) and five time periods ( 12 Apr. 2017, 13 June 2017, 15 June 2017, 18 Dec. 2017, and 20 Feb. 2018) was assessed. Leaf samples were collected based on a tissue-sampling protocol, chlorophyll meter (SPAD) values were collected, and leaves were analyzed for total $\mathrm{N}$ concentration. Data were analyzed statistically using linear regression. Leaf tissue $\mathbf{N}$ concentration had a positive monotonic relationship to SPAD values for both macadamia cultivars, both locations, and all sampling periods. The sampling period of Apr. 2017 for 'Kakea' macadamia had the greatest $R^{2}$ value for the linear regression at 0.85 . The Feb. 2018 sampling period had an $R^{2}$ value for the linear regression of 0.74 . 'Kau' macadamia had the greatest $R^{2}$ value for the linear regression of 0.24 in the Dec. 2017 sampling period. The slopes of the two macadamia cultivars for June 2017 were different from each other, suggesting that $\mathrm{N}$ recommendations need to be customized for specific macadamia cultivars if sampled in summer. The chlorophyll meter can be used for general estimation of tissue $\mathrm{N}$ in macadamia. Additional methods need to be considered and researched to refine procedures for direct estimation of total $\mathrm{N}$ concentration when using the chlorophyll meter.

$\mathrm{M}$ anagement of $\mathrm{N}$ in macadamia orchards is of primary concern for growers. Plant $\mathrm{N}$ status is a factor that affects plant vigor, yield, and quality of the macadamia kernel. Accumulation of $\mathrm{N}$ occurs in macadamia leaves during the fall and winter periods (Stephenson and Cull, 1986). Leaf $\mathrm{N}$ declines in the spring during active growth and flowering and is lowest during late summer. Analysis of leaf tissue for nutrient concentration is the accepted method to assess the nutritional status of macadamia crops (Cooil et al., 1953; Guest, 1953; Hirae, 1976; Wallace, 1971). Optimal leaf

Received for publication 14 Jan. 2019. Accepted for publication 7 Mar. 2019.

Published online 12 April 2019.

Department of Tropical Plant and Soil Science, University of Hawai'i at Manoa, Komohana Research and Extension Center, 875 Komohana Street, Hilo, HI 96720

${ }^{1}$ Corresponding author. E-mail: rgalanti@hawaii.edu. This is an open access article distributed under the CC BY-NC-ND license (https://creativecommons.org/ licenses/by-nc-nd/4.0/).

https://doi.org/10.21273/HORTTECH04276-19 tissue $\mathrm{N}$ recommendations range from $1.45 \%$ to $2 \%$ (Bittenbender and Hirae, 1990) in Hawai'i and from $1.4 \%$ to $1.5 \%$ in Australia (Stephenson and Cull, 1986). Nagao and Hirae (1992) reported a reduction in macadamia tree growth when $\mathrm{N}$ leaf concentrations were less than $1.22 \%$ and is implicated in yield variability (Stephenson and Cull, 1986). The current practice of collecting leaf samples is time-consuming and expensive for growers to adopt. The current recommended selection criteria are that: 1 ) the terminal bud of the branch is not flushing, 2) the branch tissue is woody directly up to the terminal bud to ensure uniform maturity, and 3) the apical meristem bud is not swelling (Hirae, 1976). Selected leaves are exposed to full sun, mature, undamaged, and on the second node from the terminal bud (Hirae, 1976). Leaf selection criteria for tissue analysis are subjective and timing the collection based on plant ontogeny could make collection even more complicated (Nagao and Hirae, 1992;
Stephenson et al., 1986). Leaf $\mathrm{N}$ concentration fluctuates depending on the maturity of the leaf, where $\mathrm{N}$ is high in recently matured leaves and is readily mobilized from the oldest leaves during vegetative flushes (Nagao and Hirae, 1992). There are few diagnostic laboratories available to growers in Hawai' $i$, and these are often several hours away, require air freight, or have limited availability, which could lead to less-accurate results. As a result of the aforementioned reasons, only a small subset of trees is selected for analysis, which can lead to inaccurate recommendations for the rest of the orchard. Having an affordable and rapid method to assess $\mathrm{N}$ levels on-site would be a great benefit to macadamia growers.

Chlorophyll and other components related to chlorophyll account for $\approx 75 \%$ of leaf $\mathrm{N}$ (Loomis, 1997), making chlorophyll a fairly accurate indicator for $\mathrm{N}$ status in leaves. The SPAD-502 Chlorophyll Meter (Konica Minolta, Osaka, Japan) is a portable, handheld device developed to quickly and nondestructively measure foliar $\mathrm{N}$. Chlorophyll meters measure relative chlorophyll concentration. The SPAD-502 emits two wavelength regions of light that peak at 650 and $940 \mathrm{~nm}$ through the leaf (Minolta Co., 1989). Chlorophyll absorbs light at $650 \mathrm{~nm}$ and reflects light at $940 \mathrm{~nm}$. The amount of each wavelength that is transmitted through the leaf is collected by a photodiode in the meter and converted to volts and subsequently valued. These values are used in an equation to form an empirical relationship by the meter's microprocessor. The reading output (SPAD) is in an arbitrary unit between 0 and 100 that is proportional to the amount of chlorophyll.

The chlorophyll meter originally was developed for measuring foliar $\mathrm{N}$ in rice [Oryza sativa (Chubachi et al., 1986)] and has been positively correlated with destructive chlorophyll measurements in rice, wheat (Triticum aestivum), soybean (Glycine max), and corn (Zea mays) (Ahmad et al., 2012; Monje and Bugbee, 1992). The meter's use has since been expanded to include research in hardwood and fruit trees (Chang and Robinson, 2003; Hardin et al., 2012; Neilsen et al., 1995; Netto et al., 2005). A chlorophyll meter 
could be useful for assessing tissue $\mathrm{N}$ levels in macadamia orchards, but there has been no reported data correlating SPAD values and leaf tissue $\mathrm{N}$ for macadamia. The objective of this study was to evaluate the relationship between SPAD values obtained on site to corresponding $\mathrm{N}$ tissue analysis.

\section{Materials and methods}

Tissue SAMPLING AND NUTRIENT ANALYsIs. The materials selected for this study were obtained from plants at two private farms on Hawai' $i$ Island: Pahala (lat. $19^{\circ} 13^{\prime} 40.2^{\prime \prime} \mathrm{N}$, long. $155^{\circ} 28^{\prime} 7.8^{\prime \prime} \mathrm{W}$ ) and Kapa'au (lat. $20^{\circ} 11^{\prime} 59.3^{\prime \prime} \mathrm{N}$, long. $155^{\circ} 46^{\prime} 9.2^{\prime \prime} \mathrm{W}$ ) (Table 1). Sampling numbers differed because this experiment was using data collected on leaf samples from another experiment (J. Mollinedo, $\mathrm{R}$. Gutierrez, A. Cho, M.G. Wright, and R. Galanti, unpublished data) for the 13 June 2017 and 18 Dec. 2017 sampling periods. The 12 Apr. 2017 sampling period was a preliminary sample to assess the potential of using the chlorophyll meter as an assessment tool for N. All samples were collected as composite samples consisting of 15 leaves per sample from each tree, based on current sampling protocols. The chlorophyll meter was calibrated each time before the data collection. Each leaf was measured using the chlorophyll meter by placing the measuring head onto the middle of the leaf blade, adjacent to the leaf mid rib, and then recording the SPAD value. The leaf was then collected for destructive composite sampling. Leaves were taken to Komohana Research and Extension Center (Hilo, HI), rinsed, air dried, and sent to University of Hawai'i at Manoa's Agricultural Diagnostic Service Center in Honolulu. Total $\mathrm{N}$ was analyzed at Agricultural Diagnostic Service Center using a carbon/ $\mathrm{N}$ analyzer (CN-2000;

Table 1. Sampling period, location, cultivar, and number of samples for macadamia trees sampled for SPAD values using a chlorophyll meter and foliar nitrogen in two locations on Hawai' $i$ Island.

\begin{tabular}{lclc}
\hline Sampling period & Location & Cultivar & Samples (no.) \\
\hline 12 Apr. 2017 & Kap'au & Kakea & 8 \\
13 June 2017 & Kap'au & Kakea & 50 \\
15 June 2017 & Pahala & Kau & 31 \\
18 Dec. 2017 & Pahala & Kau & 16 \\
20 Feb. 2018 & Kap'au & Kakea & 50 \\
\hline
\end{tabular}

LECO Corp., Saint Joseph, MI). Data on leaf tissue iron $(\mathrm{Fe})$ for the 13 June 2017 and 18 Dec. 2017 sampling periods for 'Kau' macadamia were provided for this study from another experiment (J. Mollinedo, R. Gutierrez, A. Cho, M.G. Wright, and R. Galanti, unpublished data).

Statistical analysis. All data were subjected to analysis of variance (ANOVA) using JMP Pro (version 13.1; SAS Institute, Cary, NC). Linear regressions were fitted for foliar $\mathrm{N}$ concentrations on SPAD values. Linear regressions were fitted for foliar Fe concentrations on SPAD values. One-way analysis of covariance with interaction simple slopes test model was used to determine differences between slopes.

\section{Results and discussion}

Cultivar Kakea. For 'Kakea' macadamia, foliar $\mathrm{N}$ concentrations ranged from $1.22 \%$ to $2.22 \%$ in Apr. 2017 , from $0.25 \%$ to $1.96 \%$ in the June 2017 , from $0.88 \%$ to $1.93 \%$ in the Feb. 2018 sampling period. Mean $\mathrm{N}$ concentration was significantly lower $(P<0.0001)$ in June $(1.12 \%)$ compared with the February $(1.50 \%)$ sampling period. Mean SPAD values were significantly different between sampling periods $(P=0.01)$. SPAD values ranged from 50.4 to 54.3 in Apr. 2017, from 41.7 to 57.5 in June 2017, and from 35.6 to 55.9 in Feb. 2018. Regression analyses indicated a significant positive monotonic linear relationship between leaf $\mathrm{N}$ concentration and SPAD values $(P \leq$ $0.0001)$. Regression $\left(R^{2}\right)$ values for the linear regression were greatest for Feb. 2018 (Fig. 1). This $R^{2}$ value for the linear regression was the closest to the regression values from the preliminary samples collected in Apr. 2017 (Fig. 1). These high $R^{2}$ values indicate that the chlorophyll meter

Hortlechnology · June 2019 29(3) may be a good tool to predict $\mathrm{N}$ tissue concentration for 'Kakea' macadamia during the late winter to early spring period, which corresponds to the current recommendation for sampling times for leaf tissue $\mathrm{N}$ in macadamia (Nagao and Hirae, 1992). The June 2017 sampling period (Fig. 1) had the lowest $R^{2}$ value. One-way ANOVA showed that the slopes for the 15 June 2017 and 20 Feb. 2018 sampling periods for 'Kakea' macadamia were significantly different (Table 2). This difference between the slopes of the sampling periods (Table 2) and the low $R^{2}$ value for the June 2017 'Kakea' macadamia linear regression (Fig. 1) indicated that use of a SPAD meter to determine tissue $\mathrm{N}$ concentrations might not be representative for June sampling periods in Hawai'i. Seasonal differences in prediction of $\mathrm{N}$ concentration from SPAD values also were seen in cottonwood (Populus deltoides) and benjamin fig (Ficus benjamina) (Loh et al., 2002) as well as apple [Malus $\times$ domestica (Neilsen et al., 1995)]. Changes in the chlorophyll meter's response based on seasonality may be related to rhythmic vegetative growth patterns. Macadamia leaf tissue $\mathrm{N}$ concentration is low and variable during the summer months (Nagao and Hirae, 1992). Seasonal source-sink relationships between vegetative and reproductive growth also influence leaf $\mathrm{N}$ status; for example, developing fruits during the summer act as an $\mathrm{N}$ sink (Fletcher et al., 2009). While it is known that increasing $\mathrm{N}$ supply increases chlorophyll concentration and activity (Cheng and Fuchigami, 2000), Prsa et al. (2007) found that chlorophyll concentration did not follow the same patterns as leaf tissue $\mathrm{N}$ concentration in apple leaves over the growing season. For example, as leaf tissue $\mathrm{N}$ concentration decreased, chlorophyll a content increased. This finding suggests that sampling time also plays a role in the relationship between leaf tissue $\mathrm{N}$ and chlorophyll and thus the ability of SPAD to estimate leaf tissue N.

Cultivar Kau. For 'Kau' macadamia, foliar $\mathrm{N}$ concentrations ranged from $1.25 \%$ to $2.85 \%$ for June 2017 and from $0.94 \%$ to $1.91 \%$ for Dec. 2017. Mean N concentration was significantly greater $(P<0.0001)$ in June $(1.98 \%)$ compared with the 

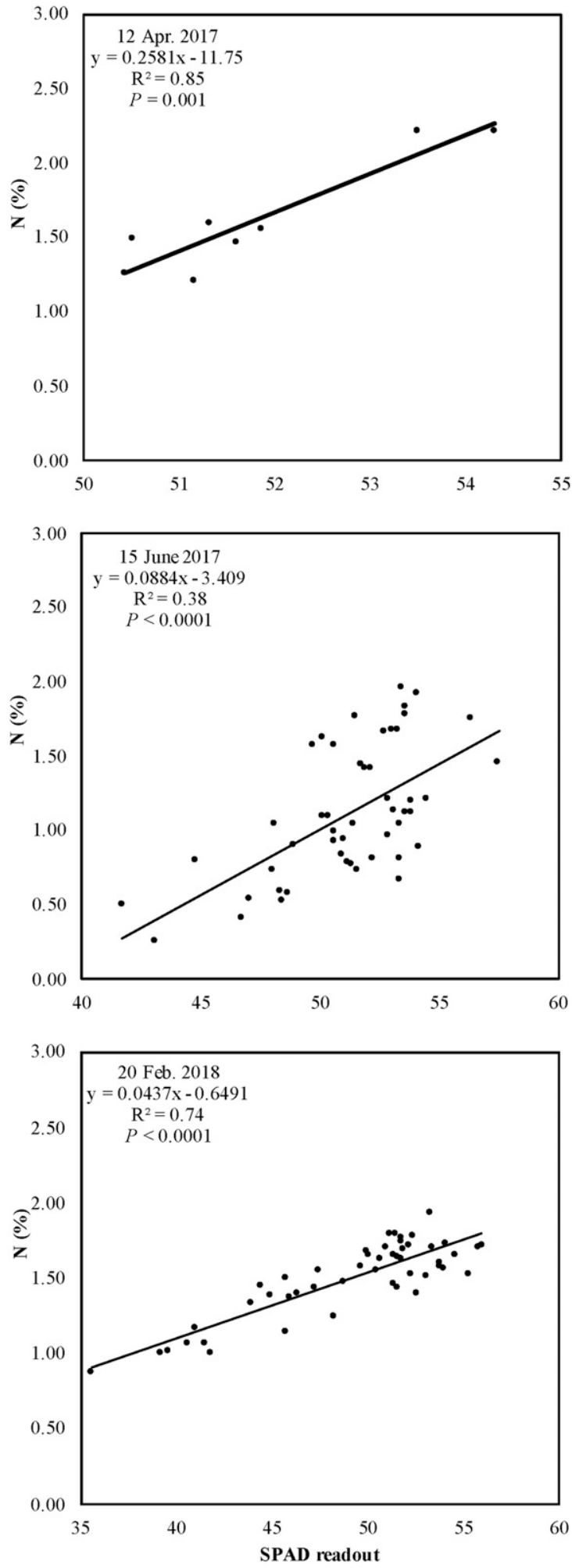

Fig. 1. Regression analysis for foliar nitrogen $(\mathrm{N})$ concentration by chlorophyll meter (SPAD) value for eight 'Kakea' macadamia trees sampled on 12 Apr. 2017 and 50 'Kakea' macadamia trees sampled on 15 June 2017 and 20 Feb. 2018 in Kapa'au, HI.

December $(1.41 \%)$ sampling. This pattern of lower range of $\mathrm{N}$ concentration in December compared with June was similar in 'Kakea' macadamia. Mean
SPAD values were not significantly different between sampling periods $(P=0.16)$. SPAD values ranged from 44.5 to 59.1 for June and from 45 to
Table 2. One-way analysis of covariance testing differences between the slopes of regression models comparing chlorophyll meter (SPAD) values with foliar nitrogen using the Student's $t$ test on two macadamia cultivars at four sampling periods on Hawai'i Island.

\begin{tabular}{lccc}
\hline $\begin{array}{l}\text { Comparison } \\
\text { of slopes }\end{array}$ & Estimate & $\begin{array}{c}\boldsymbol{t} \\
\text { ratio }\end{array}$ & $\begin{array}{c}\boldsymbol{P} \\
\text { value }\end{array}$ \\
\hline $\begin{array}{l}\text { June 2017 } \\
\text { 'Kakea' vs. }\end{array}$ & 0.0437 & 2.54 & $\mathbf{0 . 0 1 2} \mathbf{2}^{\text {z }}$ \\
$\begin{array}{l}\text { Feb. 2018 } \\
\text { 'Kakea' }\end{array}$ & & & \\
$\begin{array}{l}\text { June 2017 } \\
\text { 'Kau' vs. }\end{array}$ & 0.0117 & 0.04 & 0.74 \\
$\begin{array}{l}\text { Dec. 2017 } \\
\text { 'Kau' }\end{array}$ & & & \\
$\begin{array}{l}\text { June 2017 } \\
\text { 'Kakea' vs. }\end{array}$ & 0.0296 & 1.01 & 0.31 \\
$\begin{array}{l}\text { June 2017 } \\
\text { 'Kau' }\end{array}$ & & & \\
$\begin{array}{l}\text { 'Values in bold indicate a statistically significant } \\
\text { difference with a } P \leq 0.05 .\end{array}$ & &
\end{tabular}

55.1 for December. The $R^{2}$ value for the linear regression for 'Kau' macadamia June sampling (Fig. 2) was relatively close to the $R^{2}$ value for December sampling (Fig. 2). The slopes of the linear regressions were compared with each other (Table 2). These data indicate that the chlorophyll meter cannot be used for estimation of leaf tissue N concentration for 'Kau' macadamia during June and December. One-way ANOVA indicated that the slopes were not significantly different from each other. This contradiction to the slope comparison in 'Kakea' macadamia can be explained by the sampling periods. Seasonality has been shown to alter the accuracy of the chlorophyll meter in annual species (Chapman and Barreto, 1997; Waskom et al., 1996). In contrast, seasonality mostly did not have an effect on SPAD-N linear relationships in the hardwood sweetgum [Liquidambar styraciflua (Chang and Robinson, 2003)].

'Kakea' and 'Kau' macadamia were compared for June 2017 sampling period (Table 3 ). Samples were taken at similar periods for this sampling period and could be compared with each other. Both $\mathrm{N}$ concentration and SPAD values were significantly greater in 'Kau' than 'Kakea' macadamia in June 2017 (Table 3). This finding further corroborates some ability of the chlorophyll meter to 

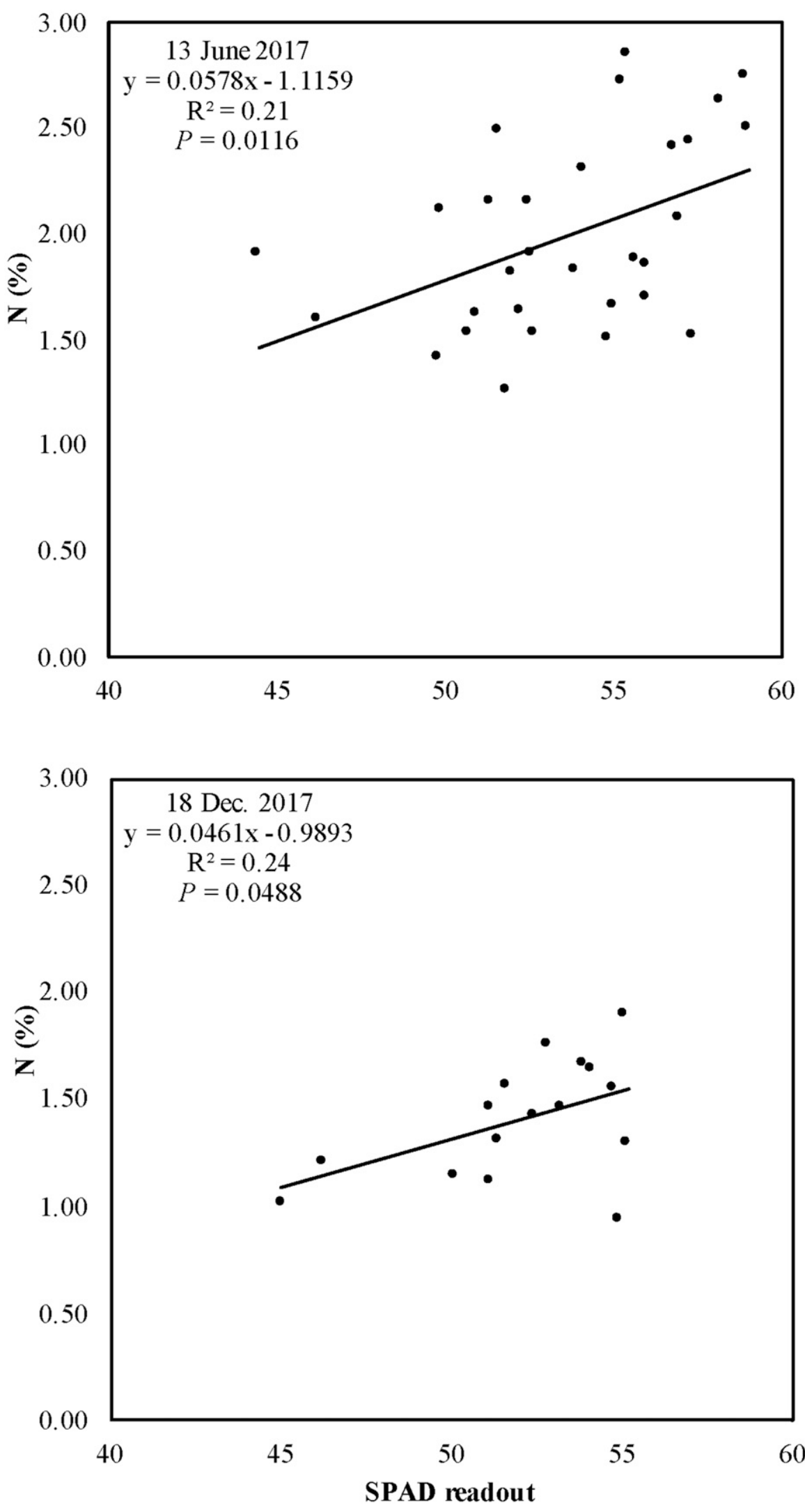

Fig. 2. Regression analysis for foliar nitrogen $(\mathrm{N})$ concentration by chlorophyll meter (SPAD) value for 32 'Kau' macadamia trees sampled on 13 June 2017 and 16 'Kau' macadamia trees sampled on 18 Dec. 2017 in Pahala, HI.
Table 3. One-way analysis of variance testing difference between means of foliar nitrogen $(\mathrm{N})$ and chlorophyll meter (SPAD) values for two macadamia cultivars sampled on Hawai'i Island in June 2017 using the Student's $t$ test.

\begin{tabular}{|c|c|c|}
\hline $\begin{array}{l}\text { Date and } \\
\text { cultivar }\end{array}$ & N (\%) & SPAD \\
\hline $\begin{array}{l}\text { June } 2017, \\
\text { Kau }\end{array}$ & 1.98 & 53.4 \\
\hline $\begin{array}{c}\text { June } 2017, \\
\text { Kakea }\end{array}$ & 1.12 & 51.2 \\
\hline Significance & $P<0.0001^{\mathrm{z}}$ & $P=0.0006$ \\
\hline
\end{tabular}

predict $\mathrm{N}$ concentration in leaf tissue. Considering the large differences in $\mathrm{N}$ concentration between these two macadamia cultivars during June 2017 sampling period, generalized optimum leaf tissue $\mathrm{N}$ recommendations may need to be refined for popular macadamia cultivars if sampling during nonrecommended sampling periods. The winter sampling periods had more similar mean $\mathrm{N}$ concentration than the summer sampling periods for the two macadamia cultivars. Different macadamia cultivars may have discrete levels of leaf tissue $\mathrm{N}$ while having varying health and yield. This study corroborates previous statements that the chlorophyll meter can be used in comparative studies for general changes in leaf tissue $\mathrm{N}$ concentration and is not suitable for absolute estimates without further improvement (Hardin et al., 2012; Loh et al., 2002), and justifies its use in comparative studies in macadamia. Potential techniques to improve the accuracy of these equations could be expressing $\mathrm{N}$ as weight per leaf area (Wu et al., 1998), and by including leaf moisture content as a variable in the regression (Chang and Robinson, 2003); these measurements were not collected for this study. Further limitations in the use of the chlorophyll meter are variations in leaf thickness and color on a leaf subsample (Chang and Robinson, 2003); these factors can decrease the accuracy of the meter (Chapman and Barreto, 1997). Additional suggested options were to collect multiple readings from each leaf subsample and use averaged values.

The accuracy of SPAD readings could be affected by interactions with 
other nutrients. Regression analyses (Fig. 3) indicate that there was no significant relationship between SPAD values and $\mathrm{Fe}$ in macadamia leaf tissue for the June 2017 sampling period for 'Kau' macadamia. Regression for the Dec. 2017 sampling period for 'Kau' macadamia indicate that there is a significant positive monotonic relationship between SPAD values and Fe concentrations (Fig. 3). The December sampling period had a greater average Fe concentration of $88 \mu \mathrm{g} \cdot \mathrm{g}^{-1}(\mathrm{ppm})$ compared with the June sampling period with an average $\mathrm{Fe}$ concentration of $54 \mu \mathrm{g} \cdot \mathrm{g}^{-1}$. Recommended leaf tissue $\mathrm{Fe}$ is 50 $\mu \mathrm{g} \cdot \mathrm{g}^{-1} \quad$ Bittenbender and Hirae, 1990). The lower average Fe concentration in the June 2017 sampling period could cause a weaker relationship between tissue $\mathrm{N}$ and SPAD values because deficient $\mathrm{Fe}$ is linked to a reduction of chlorophyll content and photosynthetic ability (Pushnik et al., 1984). Iron has been correlated to SPAD values in olive [Olea europaea (Benitez et al., 2002)] and peach [Prunus persica (Sotomayor et al., 2014)]. The lower Fe concentration could have caused a reduction in chlorophyll content or activity and reduce the "greenness" of the plant that the chlorophyll meter is measuring. Nitrogen also did have a greater correlation to SPAD values and a higher $\mathrm{Fe}$ concentration in the Dec. 2017 sampling period $(\mathrm{Fe}=$ $\left.88 \mu \mathrm{g} \cdot \mathrm{g}^{-1}\right)$ compared with the June $\left(\mathrm{Fe}=54 \mu \mathrm{g} \cdot \mathrm{g}^{-1}\right)$.

\section{Conclusion}

This experiment indicates that the chlorophyll meter could be used to estimate leaf $\mathrm{N}$ concentration in macadamia but would need refinement to be used by growers or consultants as a tool for $\mathrm{N}$ management. The meter was only adequately accurate for 'Kakea' macadamia during the recommended sampling period for leaf tissue $\mathrm{N}$ determination (late winter early spring). The regression with the greatest correlation explained $85 \%$ of the variation around the mean for correlation of SPAD value and $\mathrm{N}$ concentration whereas the lowest explained only $20 \%$ of the values. The response of the chlorophyll meter was dependent on season and macadamia cultivar, so distinct equations may need to be developed based on macadamia cultivar and sampling period,


Fig. 3. Regression analysis for foliar iron $(\mathrm{Fe})$ concentration by chlorophyll meter (SPAD) value for 32 'Kau' macadamia trees sampled on 13 June 2017 and 16 'Kau' macadamia trees sampled on 18 Dec. 2017 in Pahala, HI; $1 \mu \mathrm{g} \cdot \mathrm{g}^{-1}=1 \mathrm{ppm}$.

both of which may lead to better predictions and results. Some potential options to improve the chlorophyll meter's response without developing distinct equations for macadamia cultivars would be multiple measurements on leaf subsamples, factoring in leaf moisture content and Fe concentrations, and using $\mathrm{N}$ weight per leaf area. Further studies could focus on 
using refined methods for improving chlorophyll meter response and including more macadamia cultivars and sampling periods to understand the relationship between SPAD, leaf tissue $\mathrm{N}$ concentrations, season, and specific macadamia cultivar, and leaf tissue $\mathrm{Fe}$ concentrations.

\section{Literature cited}

Ahmad, A.A., A. Fares, and N.V. Hue. 2012. Nitrate dynamic in a tropical Mollisol amended with organic manures, planted with sweet corn, and monitored with SPAD readings. Commun. Soil Sci. Plant Anal. 43:2274-2288.

Benitez, M.L., V.M. Pedrajas, M.C. del Campillo, and J. Torrent. 2002. Iron chlorosis in olive in relation to soil properties. Nutr. Cycl. Agroecosyst. 62:47-52.

Bittenbender, H. and H. Hirae. 1990. Common problems of macadamia nut in Hawai'i. College Trop. Agr. Human Resources, Univ. Hawai'i Res. Ext. Ser. No. 112.

Chang, S. and D. Robinson. 2003. Nondestructive and rapid estimation of hardwood foliar nitrogen status using the SPAD-503 chlorophyll meter. For. Ecol. Mgt. 181:331-338.

Chapman, S.C. and H.J. Barreto. 1997. Using a chlorophyll meter to estimate specific leaf nitrogen of tropical maize during vegetative growth. Agron. J. $89: 557-562$.

Cheng, L. and L.H. Fuchigami. 2000. $\mathrm{CO}_{2}$ assimilation in relation to nitrogen in apple leaves. J. Hort. Sci. Biotechnol. 75:383-387.

Chubachi, T., I. Asano, and T. Oikawa. 1986. The diagnosis of nitrogen nutrition of rice plants using chlorophyll meter. Soil Sci. Plant Nutr. 57:190-193.

Cooil, B., M. Awada, S. Nakata, and M. Nakayama. 1953. Leaf concentrations associated with deficiencies of nitrogen, potassium, and phosphorous in macadamia. Hawai'i Agr. Expt. Sta., Univ. Hawai'i Program Notes No. 88.

Fletcher, A., H. Rennenberg, and $S$. Schmidt. 2009. Nitrogen partitioning in orchard grown Macadamia integrifolia. Tree Physiol. 30:244-256.

Guest, P. 1953. A comparison of certain chemical constituents of green and chlorotic macadamia leaves. Proc. Amer. Soc. Hort. Sci. 42:104.

Hardin, J., M. Smith, P. Wekler, and B. Cheary. 2012. In situ measurement of pecan leaf nitrogen concentration using a chlorophyll meter and vis-near infrared multispectral camera. HortScience 47: 955-960.

Hirae, H. 1976. Leaf and soil analysis in macadamia. Hawai'i Macadamia Producers' Assn. 16 ${ }^{\text {th }}$ Annual Proc. 65.

Loh, F., J. Grabosky, and N. Bassuk. 2002. Using the SPAD 502 meter to assess chlorophyll and nitrogen content of benjamin fig and cottonwood leaves. HortTechnology 12:682-686.

Loomis, R. 1997. On the utility of nitrogen in leaves. Proc. Natl. Acad. Sci. USA 94:13378-13379.

Minolta Co. 1989. Chlorophyll meter SPAD-502 manual. 3 Apr. 2019. <https://www.konicaminolta.com.cn/ instruments/download/manual/pdf/ SPAD-502_Manual.pdf $>$.

Monje, O.A. and B. Bugbee. 1992. Inherent limitations of nondestructive chlorophyll meters: A comparison of two types of meters. HortScience 27:69-71.

Nagao, M. and H. Hirae. 1992. Macadamia: Cultivation and physiology. Crit. Rev. Plant Sci. 10:441-470.

Neilsen, D., J. Hogue, G. Neilsen, and P. Parchomchuk. 1995. Using SPAD502 values to assess the nitrogen status of apple trees. HortScience 30:508-512.
Netto, A.T., E. Campostrini, J.G. Oliveira, and R.E. Bressan-Smith. 2005. Photosynthetic pigments, nitrogen, chlorophyll a fluorescence and SPAD-502 readings in coffee leaves. Scientia Hort. 104:199-209.

Pushnik, J.C., G.W. Miller, and J.H. Manwaring. 1984. The role of iron in higher plant chlorophyll biosynthesis, maintenance and chloroplast biogenesis. J. Plant Nutr. 7:733-758.

Prsa, I., F. Stampar, D. Vodnik, and R. Veberic. 2007. Influence of nitrogen on leaf chlorophyll content and photosynthesis of 'Golden Delicious' apple. Acta Agr. Scand. B Soil Plant Sci. 57:283-289.

Sotomayor, C., R. Ruiz, and J. Castro. 2014. Growth, yield and iron deficiency tolerance level of six peach rootstocks grown on calcareous soil. Cienc. Investig. Agrar. 41:403-409.

Stephenson, R. and B. Cull. 1986. Standard leaf nutrient levels for bearing macadamia trees in South East Queensland. Scientia Hort. 30:73.

Stephenson, R., B. Cull, and D. Mayer. 1986. Effects of site, climate, cultivar, flushing, and soil and leaf nutrient status on yields of macadamia in south east Queensland. Scientia Hort. 30:227-235.

Wallace, A. 1971. Regulation of micronutrient status of plants by chelating agents and other factors. Edwards Brothers, Ann Arbor, MI.

Waskom, R.M., D.G. Westfall, D.E. Spellman, and P.N. Soltanpour. 1996. Monitoring nitrogen status of corn with a portable chlorophyll meter. Commun. Soil Sci. Plant Anal. 27:545-560.

Wu, F.B., L.H. Wu, and F.H. Xu. 1998. Chlorophyll meter to predict nitrogen side dress requirements for short-season cotton (Gossypium hirsutum L.). Field Crops Res. 56:309-314. 